\title{
Index to Vol. 63 (2002)
}

\author{
Compiled by Kathy L. (Kit) Dusky
}

A

"Abell Library at Austin College's bulletin board" photo, Means, 587

"ABI/INFORM subscribers receive expanded access to backfiles," 706

"Academic Health Sciences Libraries and OhioLINK join LibQual+ survey," $5-6$

Academic Libravies Thends and Stativics, 2000 "2000 ACRL statistics at your fingerips" \& photo, 94

Academic or Research Librarian of the Year Award, 2002, 195; 2003,588

"Access services and RILI- great partnership opportunities," Obetlander, 666-68

Acquisitions (by A/T/S): African Anerican composers (Dawson), 221; Amencan cookery (Brownstone), 451; Architects (Ford), 301; Attomeys (Gilbson, 676-77; Gosnell, 676-77; Nicholas, 676-77); Authors (Cox, 300-301; Dickey, 452; Driggs, 743; Ellroy, 743; Kelton, 300-301; Maugham, 452; Prange, 379; Sontag, 600); Bird, Ulmer (publishers), 300-301; Brownstone, Cecily (American cookery), 451; Canadian fiction publisher (Praine Fire), 301: Cattle claims (Hinnant), 300-301: Civil War matenals, 676; Composers (Harbach), 452; Computer science (Shneiderman), 520-21 (\& port); Correspondence (Earhart, 676; Jones, Washington, 521 (\& photo.)); Coville (Warren \&

\section{Guide to index}

FIING is word-by-word (ALA, 1968).

Arrriviamons: Standard abbreviations are used except in titles. Names of some organizations, ALA, ACRL, LC, etc., are also abbreviated and are alphabetized as if spelled. out.

SPECTAL AhBRIVIATIONS:

$\begin{array}{ll}\text { appt. } & \text { appointment } \\ \text { f. } & \text { foundation } \\ \text { port. } & \text { portrait } \\ \text { prof. } & \text { profile } \\ \text { prog. } & \text { program }\end{array}$

Specal usages: More than one reference per page is indicated in pareatheses. Under the heading "Acquisitions (by author, subject, or title)" parentheses may enclose donors' names (for subjects) or subjects (for named collections).
Margot) Coll (photographers), 48, Cox, Mike (authors), 300 301; Criminologists (Green), 831; Dawson, William Levi (African American composers), 221; Dickey, James (poets, authors), 452: Driggs, Frank (authors, music historians, oral histories), 743; Earhart, David (correspondence), 676; Early Buddhist Manuscripts Project, 677; Edelstein, J. M. (poetry), 136; Educators (white), 48; Ellroy, James (authors), 743 Family Life Film Center (Kaufman, C. S.), 452; Ferry Hil Ledger (1797-1804), 676; Fiction coll (Roberts), 378; Ford, O'Neil (architects), 301; Gibson, lanty (attomeys), 676-77; Gosnell, William (attorneys), 676-77; Green, Alice P (criminologists), 831; Harbach, Barbara (composers, music), 452; Harte, Houston (publishers), 300-301; Hinnant, Bill (cattle claims), 300-301; Hirsch, Caesar (otorhinolaryngology) 451; Historic libary shelving system (MacDonald), 831, Hist (Prange), 379; Ingles Family Bible (1823), 676; Jones, John Paul (correspondence), 521 (\& photo); Junell, Rob (politicians), 300-301; Kaufman, Charlonte Schnee (vitamin therapy research), 452; Kaufman, William (vitamin therapy research), 452; Kelton, Elmer (authors), 300-301; Levitt, Arthur (U.S. Securittes \& Exhange Commission), 831; McCarthy, Eugene J. (U.S. Senator), 600; Macdonald, Angus Snead (historic library shelving system), 831; Maugham, W Somerser (authors), 452; Middle East coll. (Naff), 600; Modem Poetry Library, 136; Music (Harbach), 452; Music historians (Driggs), 743; Naff, Thonas (Middle East coll.), 600; Nicholas, Dallas (attomeys), 676-77; Oral histories (Driggs), 743; Organ transplants (Starzl), 48; Otorhinolaryngology (Hirsch), 451; Photographers (Coville, 48; White, 48); Poetry (Edelstein), 136; Poets (Dickey), 452; Politicians (Junell), 300-301; Prairie Fire (Canadian fiction publisher), 301- Prange, Gordon W. (authors, hist., 379; Publishers (Bird, 300-301: Harte, 300301); Roberts, Snow L. and B.W.C. (fiction coll.), 378; Shneiderman, Ben (computer science), 520-21 ( $\&$ port.); Sontag, Susan (auchors), 600; Starzl, Thomas (organ transplants), 48; U.S. Securities \& Exhange Commission (Levit), 831; U.S. Senaror (McCarthy), 600; Vitamin therapy research (Kaufman, W. \& C. S.), 452; WAMC Radio stations, 743; Washington, George (correspondence), 521 ( $\&$ photo); White, Clarence $\mathrm{H}$ (educators, photographers), 48

Acquisitions (by institution)., Angelo State U., 300-301; Boston U., 452; Columbia U., 831; E. Carolina U., 378; Emory U., 136, 221; Fla. Int. U., 831; LC, 48; NYU, 451 ; Portland State U., 600 ; U.S. Naval Acarlemy, 521 ( $\&$ photo); U. at Albany, 743, 831 UCLA, 451, 600; U. of Manitoba, 301; U. of Md, 379, 676-77; U of Md. Coll Park, 520-21 (\& port); U. of Mich, 452; U. of Minn., 600; U. of Mo., Kansas City, 743; U. of Pitsburgh, 48; U. of S. Carolina, 452, 743; U. of Tex., Auscin, 301; U of Wash., 677 Va. Tech's Digital Lib, \& Archives, 676; Wilmington Coll. 452

Adalian, Paul T., appt., 455

\section{About the author}

Kathy L. (Kit) Dusky is cataloger/associate professor at Portland State University; e-mail: duskyk@pdx.edu 
Adams, Mignon, "How useful is your homepage?. a quick and practical approach to evaluating a library's Web site," 590-92 Addis, Louise, news note, 834

"AASIS and the African American Funnel Project," ALA, Midwinter Meeting, 2002, 186

AHHSL, "AAHSL offers free electronic recruitment guide," 412 "Alaska libraries select Sirsi's Unicorn," 554

Albrect, Jean, retired, 524

Alexander, Martha, retired \& port., 746

Alexander, Otis D., appt, 455

Alibris, "Baker \& Taylor and Alibns help libraries acquire hard-to find books," 165

Alire, Camile, appt. \& port. 522

Aman, Mohammed M., news note \& port. 833

AHA, "Columbia Univ. Press and American Historical Assoc launch collection," 705

ALA, "Let freedom read: read a banned book" \& photo., 553; "Library community endorses Digital Media Consumers' Rights Act," 704; Posters of the Liburay War Senvice, "Hey Fellows," poster 3 (photo, cover, no 1)

ALA, Annual Conference, 2002, "Annual Conference audiocassettes available," 558; "ACRL in Atlantá: ACRL's programs at the ALA Annual Conference" \& photos., 556 65. 574; "ACRL offering four preconferences in Atlanta!", 354; "ACRL programs and meetings," $\mathrm{AC}-1-\mathrm{AC}-16$ (no.5); "ACRL's new scholarly communication initiative: addressing a growng crisis," 356-658, "Instruction for first-year undergraduates: developing strategies to facilitate their transitions," 196; "Invitation to the ACRL President's program in Atlanta: the top five reasons you need to be there," 34142,377; "Legislative advocacy workshop in Atlanta," 262; "News from the University Libraries Section," 562-63; "RBMS to offer 43rd preconference in Atlanta," 166; "Register for ACRL preconferences," 258

ALA, Annual Conference, 2003, "Toronto, 2003: it's closer than you think," 490

ALA, Midwinter Meeting, 2002, "AASLS and the African American Funnel Project," 186, "ACRL at the Midwinter meeting: actions of the ACRL Board of Directors," 185-88; "ACRL programs inspire excellence: the President's Discussion Group at Midwinter," 189, 192; "Resolution honoring Martinus Nijhoff International" \& photo., 187

ALA, Midwinter Meeting, 2003, "ACRL discussion groups," 782 "ACRL Midwinter meetings in Philadelphia: a tentative schedule," 780-85, "Mark your calendar. ACRL to offer two workshops in Philadelphia," 704, 772; "Meet Dumont and Maloy—candidates for ACRL president," 784; "Open forum on ACRL the association of the future," 781 " "Want to learn more about implementing the 'Standards for college Libraries?", 712

"American Museum of Natural History Congo Expedition 19091915," rev. of, 373

Anderson, Gordon, photo., 206

Andrews, Joseph C, deceased, 681

Anne Arundel Com. Coll., "Excellence in Academic Libraries winners," 194 ( 8 port.)

"Annual Conference audiocassettes avallable," 558

"Appalachian State establishes racing collection," 772

"Applying evaluation criteria for Web-based infomation sources to paper-based infonmation sources," Doran, 640

Appointments, 51-53, $138-39,223-25,302-4,38283,455-57,522$ $24,602-3,679-80,744-46,834-35$

Apropriate use policies forcompruess in odlege thinersitylibruies(CIP note \#31) published, ACRL, 334

"Appropriate use policies for computers provided in ACRL's latest CLIP note" \& photo, 334

Arant, Wendi, "Science ficcion and fantasy? a guide to resources on the Web" \& logos, 652-55

"Archaeology and evolution: what happens when you clean your office, ${ }^{,}$Bennett, 30

Ariel, Joan, "Wins WSS Career Achievement Award," 285-86

"Armenian National Institute" \& logo, rev. of, 297-98

"Around the world in 100 days" \& photo, Mizzy, 716-17

Arsenault, Kathy, appt, 602
Ashton-Pritting, Randi Lynn, appt, 679

Ashworth, Carol, "Washington hotlne," 368, 373

"Ask a lilorarian LIVE: specialist and broad-based reference capacities expanded by new software," Parrick, 280-81

Askey, Dale, "Back to Europe: ACRL at the 53rd Frankturt Book Fair" \& photos., 204 206, 220

AAHSL, "Academic Health Sciences Libraries and OhioLINK join LibQual+ survey," $5-6$

"AAHSL offers free electronic recruitment guide," 412

ACRL, Academic or Research Libranan of the Year Award, 2002 $195 ; 2003,588$; "And the winners are ...: the official results of the 2002 ACRL elections," 436-39; "Cannon and Popko share plans for ACRL: prepare to cast your vote in the election this spring" 124-28, Divectory of leskcallectionsin acadentic, professional, and research libraries, published, 92 ( $\&$ photo); Doctoral Dissentation Fellowship, 2002, 284, 2003, 589; "Don't be left out: sign up for ACRL e-mail updates," 554; Excellence in Acadenic Libraries Award, 2002, 194, 196, 413 (photo); 2003, 588; "Friends of ACRL," 819; "Get involved at ACRL's Legislative luncheon," 283; "Get involved with ACRL volunteer to serve on a division or section committee," 659 61; Hugh C Alkinson Memorial Award, 2002,420; 2003,588 ; "Keep informed of legislative and policy issues," 554 ; "Legislative advocacy workshop in Atlanta," 262; "The library's role in distance education: survey results from ACRL's 2000 acadenic librarytrends and statistics", $338-40$, "Margot Sutton Conahan named manager of professional development for ACRL," 551; "Mark your calendar! ACRL to offer two workshops in Philadelphia," 704, 772; "Mary Jane Petrowski named ACRL senior associate executive director" \& port., 91; "Meet Dumont and Maloy-candidates for ACRI president," 784; "Meet the candidates for ALA president: vote in the election this spring" \& ports., 198-203; "Meet the staff," 820-22; "Members running for ALA Council," 202; "Membership statistics," 797; "Need to develop a plan to support distance ed?: take ACRL's new online course," 665 ; "New monograph titles for 2001-02," 811 , "News from the University Libranes Section," 562-63; "Open forum on ACRL. the association of the future," 781; "Receive advance notice of CGRL news contents," 554; "Register for ACRL preconferences," 258; "SPARC and ACRL: working together to reform scholarly communication," Johnson, 648-51; "Section committee volunteer form," 663; "Stay up-to-date on association activities and opportunities," 554; "The year in review," 801-12; "2000 ACRL statistics at your fingertips" \& photo., 94: "2002 ACRL/Harvard Leadership Institute," 93; "University of Arizona to hold conference on organizational change," 6 ; "We're looking for a few good men and women: ACRL seeks nominees for office," 282-83

ACRL, Annual, "Conference progtams-Atlanta," 2002, 799; "Preconferences," 2002, 808

ACRL, Arnual report, 2001-2002, 795-822

ACRL, Board of Directors, "AASLS and the African American Funnel Project," 186; "Charles A. Schwantz named new PII editor by ACRL board," 261; photo. \& roster, 2001-02, 813; "Resolution honoring Martinus Nijhoff Intemational" \& photo., 187

ACRL, Board of Directors, "Highlights," (Jan., 185-88), (June \& photos. 568-70)

ACRL, Budget \& Finance Comm. Charr, "Financial report" \& port., 814-18

ACR. CIS, Appropriate use policies for computers in college/ universib) libraries (CUP note *31) published, 334; CLIP notes, \#30,92;

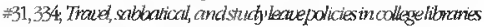
(CIIP note $\approx 30$ ) published, 92

ACRL, Committee on the Status of Academic Librarians, "Guidelines for academic status for college and university librarians," approved 2002, 664-65

ACRL, EBSS, Distinguished Education and Behavioral Sciences Librarian Award, 2002, 288; 2003, 589; "Guidelines for curriculum.materials centers: draft version," 207-13

ACRL, Exec Director, "Letter" \& port, 800

ACRL, IS, "Guidelines, guidelines, and more guidelines," 733; "Guidelines for instruction programs in academic libraries: a 
final draft." 732-35; Innovation in Instruction Award, 2002, 286; 2003,588 89; "Instuction for first-year undergraduates: developing strategies to facilitate their transitions," 196; Instruction Section Publication of the Year Award, 2002 286, 2003, 589; Miriam Dudley Instruction Librarian Award 2002,$285 ; 2003,588$; "Panel session on new IS research agenda to be held at ACRL National Conference," 773

ACRL LPSS, Marta Lange/CQ Award, 2002, 285; 2003, 588

ACRL, Midwnter, "Workshops," 2002, 809

ACRL, Midwinter Meetings, 2002, "ACRL Board of Directors actions, June 2002: highlights of the Board's annual conference meetings" \& photos, $568-70$

ACRL, National Conference, 2003. "Call for participation," 29 "Charlotte keynote speakers," 706; "Charlotte on a shoestring public art, waterscapes, historic sites, and dining" \& photos. Tierney, 646-47; "Charlotte 'revs up' for ACRL: tour's and activities in the 2003 ACRL National Conference city" \& photos. Tiemey, 728-30; "Demystifying the program selection process: how to submit a successful proposal for the 11th ACRI, National Conference, "Hardesty, 269-70, 279; "Hints for successful panel presentations: preparing for ACRL's 11th National Conference," 28-29; "Panel session on new IS research agenda to be held at ACRL National Conference," 773; "Poster session presenters sought for ACRL National Conference," 641; "Preparing for ACRL's 11th National Conference: how to create competitive contributed papers," St. Clair, 180-81; "There's still time to submit a proposal for the ACRL 11th National Conference," 340; "Tips for a successful proposal," Hardesty, 270; "Tips for successtul workshops," McAndrew, 181; "Volunteers needed at Charlotte conference, "706, 773

ACRL, President, "Message" \& port. 796-97

ACRL, RBMS, "Guidelines regarding thefts in libraries: a draft," 360-66, Katharine Kyes Leab and Dantel J. Leab American Book Prices Cument Exhibition Catalogue Awards, 2002, 286 87: 2003,589

ACRL, STS, Eunice Rockwell Oberly Award, 2003, 589

ACRL, Vice-President, "Message" \& port., 79899

ACRL, WESS, Coutts Nijhoff International West European Specialist Study Grant, 2003, 589; Martinus Nijhoff International West European Specialist Study Grant, 2002 $94,187,260-61$

ACRL, WSS, Career Achievement in Women's Studies Librananship, 2002, 285-86; 2003, 589; Significant Achievement in Women's Studies Librarianship, 2002, 286, 2003,589

"ACRL announces participants for best practices conference," 259

"ACRL at the Midwinter Meeting: actions of the ACRL Board of Directors," $185-88$

"ACRL award winners, 2002,"803

"ACRL candidates for 2002: learn who's running for office," 36 39, cortection, 139

"ACRL chapter conferences/events," 2002-03,722

"ACRL colleagues," 812

"ACRL committee volunteer form," 662

"ACRL discussion groups," 782

"ACRL Effective Practices Clearinghouse accepting submissions," 77

"ACRL/Harvard Leadership Institute," 203, 288, 334, 414

"ACRL honors the 2002 award winners. recognizing professional achievement, "Petrowski, $194-6$

"ACRL in Atlanta: ACRL's programs at the ALA Annual Conference" \& photos., 556-65.574

"ACRL journals," 810

"ACRL launches Information Literacy Web site with expert locator " 412-13

"ACRL members Lisa Hinchliffe and Arlie Sims at the American Association of Higher Education National Conference" \& photo. 412

"ACRL Midwinter meetings in Philadelphia: a tentative schedule" $780-85$

"ACRL offering four preconferences in Atlanta!", ALA, Annual Conference, 2002,354

"ACRL offers Direclony of Test Colleclionsand new CLIP notes" \& photo. 92
ACRL programs and meetings, "AC-1-AC-16 (no.5)

"ACRL programs inspire excellence. the President's Discussion Group at Midwinter," Whyte, 189, 192

"ACRL publication focuses on libtaries' impact on students" \& photo, $261-62$

"ACRL represented at 21st Century Literacy Summit" \& photo., 332

ACRL Standards \& Guidelines, "Development and revision of the guidelines," ACRL, 665; "Development of the Guidelines," ACRL, 208; "Guidelines, guidelines, and more guidelines," 733; "Guidelines for academic status for college and university librarians," ACRL, approved 2002, 664-65 "Guidelines for cuniculum materials centers: draft version," ACRL, 207-13; "Guidelines for instruction programs in academic libraries: a final draft," 732-35; "Guidelines regarding thefts in libraries: a draft," ACRL, 360-66; "History of the guidelines," ACRL, 361; "How practical are the ACRL "Standards for College Libraries? Applying standards in the acalemic libary,"711-13, Standards and asveswnent for academx librarier a workbook, 712; "Want to learn more about implementing the 'Standards for College Libraries?", 712

"ACRL takes up the challenges of scholarly communication: the year ahead for the new program officer," Martin, 786-87, 793

"ACRL's latest Webcasts focus on information literacy and assessment," 552

"ACRL's mission," 795

"ACRL's new scholarly communication initiative: addressing a growing crisis, "English, 356-658

"ACRL's 2003 awards program: recognizing outstanding achievements in academic librarianship, "Shemod, 58889

ARI "Fretwell-Downing and ARL collaborate on Scholars Portal Project," 413; "Library community endorses Digitzl Media Consumers' Rights Act," 704; "Texas A\&M University libraries and ARL receive NSF grant, "92 93; "University of Arizona to hold conference on organizational change, " 6 ; "University of Louisville becomes newest ARL member." 487 : "You don't need to know German to participate in ARL's German Resources Project," 705

ASERL, "MetaScholar Initiative established," 551; "UNC Greensboro joins ASERL," 412

Atkinson and CJCLS award committees announce 2002 winners the final installment of ACRL award winners," Sherrod, 420 425

Atkinson (Hugh C.) Memorial Award, 2002, 420; 2003, 588

Austin Coll., "Abell Library at Austin College's bulletin board" photo., 587

Awdrds, 94 (1), 187 (1), 194-96(2), 260-61, 284-88(11), 413,420(2) $425,588-89(16), 803$

B

"Back to Europe: ACRL at the 53rd Frankfurt Book Fair" \& photos., Askey, 204 206, 220

Bailey-Haner, Brenda, news note, 223

Baird, Brian J." "Consortial preservation management: a new mode for library preservation administration, " $572-74$

Baird, James, photo., 834

Bajusova, Olga, Don't forget the Fain frontispiece, watercolor illus. 409 (photo, cover, no. 6 )

Baker, Betsy, "Named IS Publication award winner," 286

Baker, Bradley, news note, 833

Baker, Shirley K., "The knotty problem of priorities and relationships: a response to the top issues," 789

Baker, William, news note, 454

Baker \& Taylor, Academic or Research Librarian of the Year Award, 2002, 195;2003,588

"Baker \& Taylor and Alibris help libraries acquire hard-to-find books," 165

"Baker \& Taylor announces e-content agreements," 411

Banister, Steven T., appt., 679

Bamard, David P., photo., 678

Bamard, Kay, photo. 678

Bames, Tamika, news note, 454

"Bames \& Noble partners with Bowker" 262

Barth, Joseph, appt., 138 
Bartosz, Kimberly, rev. ("Matrix" \& logo), 444

Baumann, Helene, photo, 206

Beall, Jeffrey, "Awarded Lazerow Fellowship" \& port, 284-85

"Becoming part of the course: using Blacklyord to extend oneshot library instruction" \& photos., Cox, 11-13, 39

Beforesune bura US goumment bond of the 2ndLibenty Loan of 1977 , poster, cover, no. 7), (photo.

Bell, Mary Margaret, "Managing reference e-mail in an archival setting: tools for the increasing number of reference queries," 99-101

Benefiel, Candace, news note, 833

Bennet, Denise Beaubien, "Archaeology and evolution: what happens when you clean your office, ${ }^{\text {" }} 30$

Berman, Sanford, "New Wel site profiles Sanford Beman papers at UIUC," $164-65$

Best, Rickey, appt, 455

"BCR activates new netLibtary Ready Reference Collection," $640-41$

Bickers, Patrick M., "New ways to acquire old books: adding outof-print titles to the library's collection, ${ }^{2} 173-75,188$

Billings, Harold W, "Named winner of Atkinson Award," 420

"Biography resources: finding information on the famous, infamous, and obscure ${ }^{n} \&$ logos, Schreiner, 32-35, 39

Birch, Tolbeylynn, appt \& port, 223-24

Bird, Judith, news note, 833

Bischof, Steve, "Computer manuals in the academic library collection: improving accessibility," $506-9$

Blackwel's Book Services, Excellence in Academic Lbranes Awand, $2002,194,196,413$ (photo), 2003, 588

Blau, Andrew, photo., 332

Block, Jane, news note, 381

Bonamici, Andrew R., "The Coalition for Networked Infonmation (CNI): reports from the task force meeting, "121-23

"Boosting libraries at university orientations: designing promotional booth"s" \& plioto, Spencer, 418-19

"Boston Athenacum renovation completed," 639

"BotSpot" \& logo, rev, of, 44

Bowker, "Bames \& Noble pantners with Bowker," 262

Bowlby, Raynna, "Living the Futuré collaboratively speaking: a Library conference on organizational renewal," 511-12, 521

Bowling Green State U., "Original valentines," 8 ) (plioto, cover; no. 2)

Bowman, Camille., "Washington hotine," 368, 373

Bradley, Lynne E., "Washington hotline," 41, 129, 214, 294, 441, $452,669,736$

"Brandeis selects Ex Libris' DigiTool," 487

Brandeis U., Music-pyntechnical, dialolicalandbutu-butical, lithograph, 701 (photo, cover, no 10); "Subject access in an interdisciplinary envitonment: meaningful signposts must be created," 415-16

Brantz, Malcolm H, "Library-sponsored faculty book-buying trips: a look at a different approdch to collection development," $264-66,292$

Breivilk, Patricia, photo, 332

Brock U., "Modeling and the use of graphics in Web tutorials: a lesson from social leaming theory" \& photos. 95-96, 119

"Brooklyn College opens expanded library," $7 / 2$

Brown, Lauren, photo., 379

Buyn Mawr Coll., Fortume, ink \& watercolor, 257 (photo, cover, no. 4)

Burckel, Nicholas, news note \& port, 522

Burtle, Laura G., "The citizen in the information age: Georgia State University's creation of a librarian-led freshmen leaming community," 276-79

Bush, Geonge W., "President's budget includes $\$ 10$ million to recruit new librarians," 163

Byrd, Theresa S., "Exciting things happen (1) your library: ACRL

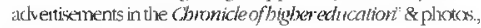
$586-87$; photos $568,570,813$

C

Calbert, Jack Lynn, retired \& port., 383

Calif Digital Lib., "UC libranies expand interlibrary loan service," 9394
Calif. Hist. Soc, Leab Award, 286-87

CSU, "New CSU infomation competence Web site," 64:1061, correction, 108

CSU, Northridge, "From cataloger to curator: the Korean exhibits of an accidental ethnic librarian" \& photos., 431-34, 452

"Call for participation," ACRL, National Conference, 2003, 29

"Call of popular culture papers," 488-89

Cambridge Scientific Abstracts, "SAGE Publications to offer. collections online," 639

Canadian Centre for Architecture, Montreal, Spear's Model Village, illus., 549 (photo, cover, no. 8)

"Canadian poetry database launched," 414

Cannon, Tyrone H., ACRL, vice-president \& port, 436, 438; "ACRL candidates for 2002: lean who's nuning for office" \& port., 36; "Cannon and Popko share plans for ACRL: prepare to cast your vote in the election this spring" \& port., 124-26; plioto, 570

"Cannon and Popko share plans for ACRL: prepare to cast your vote in the election this spring, "124-28

Cardwell, Jennifer, rev. ("Dolan DNA Leaming Center"), 516

Career Achievement in Women's Studies Librarianship, 2002, 285$86,2003,589$

Carl, Cherie, photo., 522

Carlito, Delores, rev. ("Global Exchange" \& logo), 444-45

Carlson, David H., appt. \& port., 51

"Carnegie Endowment for Intemational Peace," rev of, 297

Cartoons, $6,92,163,259,331,411,487,551,639,703,771$

Carver, Amy $\mathrm{L}_{-,}$"We are all reference librarians: using communication to employ a plitosophy of access for catalogers, ${ }^{\prime} 168-70$

Carver, Deborah, appt. \& port., 679

Cary, Shannon, port, 820

Case, Beau David, photo, 206

Case, Susan, rev. ("Center for Watershed Protection" \& logo), 672

Case, Susan B., rev. ("Invasivespecies.gov" \& logo), 132-33

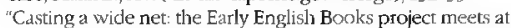
Northwestem," Garett, 117-19

Cates, Jo, appt., 51

Gazden, Robert E., deceased, 525

"Center for Watershed Protection" \& logo, rev. of, 672

"Centre College retums rare texts to Dickinson College," 412

Chapran-Smith, V., appt., 138

"Chartes A. Sclowartz named new PIL editor by ACRL board," 261

"Chanotte keynote speakers," ACRL, National Conference, 2003, 706

"Charlotte on a shoestring public art, waterscapes, historic sites, and dining" \& photos., Tiemey, 646-47

"Charlotte 'revs up' for ACRL: tours and activities in the 2003 ACRL National Conference city" \& photos., Tiemey, $728-$ 3)

Cheperon, Lois $\mathbf{H}$, photos. $568,570,813$

Chervinko, James, retired, 680

CHOICE Reviews, "RIT's Wallace Library ads CHOICE Reviews to its OPAC, 411

Cboiceketieus online, "Site kense edtion of Choicelertets onlinenow available." 331

Chistenlerry, Faye, "How to become a serial killer: one appronch to the acquisition and retention of penodicals, "103-5

Christiansen, Dorothy, retired, 139

Christopher Newport U., "T'idewater libraries develop new music collection," $552-53$

"Chm nicle launches trial of campuswide site licensing," 332, 334

Chronicleof brgbereducalion, "Exating uings lappen your liblary: ACRL advertisements in the Chronicle of highereducalion" \& photo., $586-87$

"The citizen in the information age: Georgia State University's creation of a librarian-led freshmen learning community," Burtle, 276-79

City U. of N., "Brooklyn College opens expanded library," 772

Clark, Susan E, rev. ("Camegie Endownent for International Peace"), 297

"Classification Web available through Library of Congress", 554

CLIP notes, ACRL, $\div 30,92 ; \% 31,334$ 
Cloonan, Michele V., appt., 834

"CNI and Dartmouth offer 'Collaborative Facilities' Web site," $489-90$

"The Coalition for Networked Information (CNI): reports from

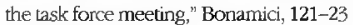

"Code Talk" \& logo, rev. of, 132

Coll of W/m. and Mary, "Tidewater libraries develop new music collection," $552-53$

CERL neus, "Job of a lifetime' ideas?", Mizzy, 739; "Share your thoughts and ideas," 715; "Statement of ownership and management," 713

"CERL new column editor wanted " 281

"CERL neus submission guidelines," 40

"College of William and Mary library undergoes renovation," 166

"Columbia Univ. contracts with National Libraty of China," 259

"Columbia Univ. Press and American Historical Assoc. launch collection," 705

"Columbia U to preserve School of Library Services collection," 450

Comer, Cynthia H., "New roles and global collabotation: the fruits of international exchange" \& photos, 106-8

"ClC brings 19th-century American fiction online," 163-64

"Committee volunteer form," ACRL, 662

Community College Leaming Resources/Library Achievement Awards, 2002, 420, 425; 2003, 589

"Complementary and alternative medicine: an overview of nontraditional medrcine on the Wels" $\&$ logos, Nims, 576-79, 589

"Computational science: an Internet introduction" \& logos, Gold, $112-16$

"Computer manuals in the academic library collection: improving accessibility, "Klassen, 506-9

Conahan, Margot Sutton, "Named manager of professional development for ACRL," 551; port., 820

Conference circuit ("Annual Conference audiocasserres available," 558; "ACRL at the Midwinter Meeting," 18588 ; "ACRL discussion groups," 782, "ACRL in Adlanta" \& photos. 556-65, 574; 'ACRL Midwunter meetings in Philadelphia,' 780-85; "ACRL programs inspire excellence, "Whyte, 189, 192; "Back to Europe" \& photos., Askey, 204 206, 220; "The Coalition for Networked Information (CN1", Bonamici, 12123; "Copyright town meeting," Poole, 182-84; "Living the Futuref," Bowlby, 511-12, 521: "Meet Dumont and Maloy. candidates for ACRL president," 784; "New roles and global collaboration" \& photos., Comer, 106-8; "Open forum on ACRL, "781; "University Libraries Section at Midwinter," Zimmerman, 291-92)

$C Q$, Marta Lange/CQ Award, 2002, 285; 2003, 588

"Consortial preservation management: a new model for library preservation administration," Baird, 572-74

Constantinou, Constantia, appt., 382

"Copyright town meeting: intellectual property and multimedia in the Digital Age," Poole, 182-84

Corbin, Brenda, news note, 678

A corecollection in dance, Edsall, ed, 78

"Comell promotes library careers to high school students," 771

Comell U., "CLIR and Comell offer Web-based tutorial," 773 "Excellence in Academic Libraries winners," 194, 196 (\& photo.); Leab Award Special Commendations for Electronic Exhibitions, 286-87

Corrections, $108,139,225,720$

Costabile, Mary, "Washington hotline," 41

"The Costume Gallery" \& logo, rev. of, 372-73

Cott, Nancy, appt., 302

Cottrell, Janet R., "Five years ago ...: comparison charts as a public relations tool," $495-97$

"CLIR and Comell offer Web-based tutorial," 773

Courtois, Martin P., "Crisis, disaster, and emergency management: Web sites for researchers" \& logos, 723-26

Coutts, Brian, "Travel on the Web: sites to help you plan your vacation" \& logos, 271-75

Coutts Nijhoff International West European Specialist Study Grant, 2003, 589
Cox, Christopher, "Becoming part of the course: using Blackboard to extend one-shot library instruction" \& photos., 11-13, 39

Creech, John, rev. ( "ECHO Science \& Technology Virtual Center"), 372

"Crisis, disaster, and emergency management: Web sites for researchers" \& logos, Coutois, 723-26

Croft, Jean Ann, photo., 716

Crosbie, Michael J, When change is set in stone an analysis of seren academiclibraries dessnediby Pem DeanRogers, Architedt 78

"Crossing borders: exploring new realities with our neighbors," Dancik, 656,677

Crowe, William J , news note, 833

\section{D}

D'Almeida, Diane, photo., 206

"Dance: a guide to Web resources" \& logos, Hansen, 776-79

Dancik, Deborah B., "ACRL's new scholarly communication initiative: addressing a growing crisis," 356-658; "Crossing borders exploring new realities with our neighbors, " 656 , 677 ; photos, $568,570,813$

Danner, Phyllis, deceased \& port., 383

Darst, Valerie, news note, 302

Dartmouth Coll., "CNI and Dartmouth offer 'Collaborative Facilities' Web site," $489-90$

DRA, "Sirsi and DRA complete merger, ${ }^{9} 92$

Daumier, Honoré, Music - pynorecbnical, diabolicalcand bumb-buntical, lithograph, 701 (photo., cover, no. 10)

Davis, Mary Ellen K., "Letrer from the executive director" \& port, 800 ; photos. $332,568,570,813$, port, 820

Dawes, Pamela, news note, 454

Deaths, $53,225,304,383,458,525,604,681,746,835$

DeLoatch, Celestine, photo. 522

"Demystifying the program selection process: how to submit a successful proposal for the 11th ACRL, National Conference," Hardesty, 269-70, 279

"Developing collaborative relationships: librarians, students, and faculty creating learning communities, ${ }^{,}$Lippincott, $190-92$

"Development and revision of the gutdelines," ACRL, 665

"Development of the Guidelines," ACRL, 208

Dickinson Coll., "Centre College renums rare texts to Dickinson College, "412; Leab Award honorable mention, 286-87

"Digital diamond sparkles at Temple," Lang, 488-89

Digital Library of $\mathrm{Ga}$., "Political cartoon collection avallable through Digital Library of Georgia," 331

"Digitally recorded texthooks available though RFB\&D," 641

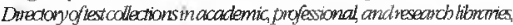
published, ACRL, 92 (\& photo.)

Distinguished Education and Behavioral Sciences Librarian Award, 2002, 288; 2003, 589

Doctoral Dissertation Fellowship, 2002, 284; 2003, 589

"DDILL : Document Delivery and Interlibrary Loan Services Guide," rev. of, 739

"Does the 'new library model' fit small- and medium-sized librares? Shippensburg University believes so," Laite, 15-17

"Dolan DNA Learning Center," rev, of, 516

Dolven, Mary, retired, 139

"Don't be left out: sign up for ACRL e-mail updates," 554

Don't forget the Fairy, fronlispiece, watercolor illus, Bajusova, 409 (photo., cover, no. 6)

Doran, Kirk, "Applying evaluation crileria for Web-based information sources to paper-based information sources," 640

"The double life of the college campus: striking a balance between reality and expectations," Welbum, 718-20

Dougherty, Richard $M$., "How useful is your homepage?: a quick and practical approach to evaluating a library's Web site," $590-92$

Driessen, Karen, retired, 457

Drobnicki, John A., rev. ("Armenian National Institute" \& logo), 297-98

Drost, Carol A "Internet reviews," 44 45, 132-33, 216-17, $297-98,372-73,444-45,516-17,596-97,672-73,738-39$ $826-27$ 
Dudley (Miriam) Instruction Librarian Award, 2002, 285; 2003 , 588

Duguid, Paul, "Charlotte keynote speakers," 706

Dumont, Paul E., "Meet Dumont and Maloy — Candidates for ACRL president," 784; photos., 568, 813

Dutka, Andrew, "Further reading, ${ }^{n} 21$; "The surprise part of a librarian's life: exhibition design and preparation course" \& photos., 19-22

Dyckman, Lise M., appt., 51

Dye, Nancy S., photo, 413

Dykgraaf, Christine, rev. ("HowStuffWorks"), 738

"Early Modern Women Database," rev. of, 596-97

Eberhart, George M., "New publications," 46 ( $\&$ phoro.), 134-35 (\& photo.), 218 20 (\& photos.), 299 (\& photo.), 301, 375-77 (\& photo), 447-78 (\& photo), 518-19, 598-99 (\& photos.), 674-75, 740-41 ( $\&$ photos.), 828-29 ( $\&$ photo.)

"ebrary launches international library program," 163

"ebrary offers new pricing model," 413

EBSCO, Community College Learning Resources/Library Achievement Awards, 2002, 420, 425; Community College Learning Resources/Library Achievement Awards, 2003, 589 "EBSCO and Sirsi forn content partnership," 772-73

"ECHO Science \& Technology Virtual Center," rev. of, 372

"Economic Policy Institute," rev. of, 673

Fckell Mary D, ed A corecollectronin dance, 7-8

Eisenberg, Michael, photo, 332

Ełsevier Science, Miriam Dudley Instruction Librarian Award, $2002,285,2003,588$

Emmons, Mark, rev. "The Costume Gallery" \& logo), 372-73

Emory U. "Metascholar Initiative established," 551

Endeavor, "Maryland Interlibrary Consortium chooses Endeavor," 332

English, Ray, "ACRL's new scholarly communication initiative: addressing a growing crisis," 356-658; photo., 413

Enniss, Stephen, news note, 223

"Environmental health: sites that focus on protecting our natural resources" \& logos, Riley, 350-54

Epp, Ronald $\mathrm{H}$, appt., 51

Errata, 108, 139, 225, 720

Escobar, Hector, "The value of campus partnerships in redesigning library instruction: administrators, faculty, and students get involved, "345-48

Funice Rockwell Oberly Award, 2003, 589

Evans, Karen, rev. ("Jewish Virtual Lilorary" \& logo), 672-73

Ex Libris, "'Brandeis selects Ex Libris' DigiTool," 487

Excellence in Academic Libraries Award, 2002, 194, 196, 413 (photo); 2003, 588

"Exciting things happen 9 your library: ACRL advertisements in the Chronicle of higheredi ualion \& photo, Hardesty, 586-87

"Extended deadline," 8

F

"Facing the competition the critical is sues of reference service," Massey-Burzo, 74475

Farthing Pat, news note, 744

"Fast facts," Viles, 86, 158, 254, 326, 406, 482, 546, 634, 698, correction, $720,766,850$

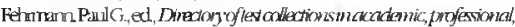
and raxanch fibiariex published, 92 ( $\&$ photo)

Fernekes, Rolyert W., "How practical are the ACRL 'Stundarcls for College Libraries? Applying standards in the academic libary," 711-13

Fetzer, Mary K., "Receives Marta Lange/CQ award," 285

"Financial Markets Center" \& logo, rev. of, 738-39

"First project underway at OCLC's netv preservation center," 641 Fitzsimunons, Richard, news note, 522

"Five steps to an effective internship program: providing a meaningul experience for intems and librarjans." Quarton 109-11

"Five years ago .... comparison charts as a puldic relations tool." Coltrell, 495-97

"Fleut donates historic building to RISD library, "261
Flood, Francis (Jim), deceased \& port., 681

Foley, Dan, deceased \& port, comection, 53, 225

Foot Soldier Project for Civil Rights Studies, "Liniversity of Georgia llbrary parners with Foot Soldier Project for Civil Rights Studies," 91

Ford, Charlotte, "Receives doctoral dissertation fellowship" \& port., 284

Forro, Denise A., "A low-tech approach: working with persons with mobility and speech disabilities in an acadernic library" \& photos., $708-10$

Fontume, ink \& watercolor, Fraser, 257 (photo, cover, no. 4)

Foster, Stephen Paul, appt. \& port., 522-23

Foudy, Gerri, rev. ("Initatuve and Referendum Instute" \& logo), 826

Franklin \& Marshall Coll., "Hey Fellows," poster, 3 (photo., cover no. 1)

Fraser, Claud Lovat, Fortume, ink \& watercolor, 257 (photo., cover, no. 4)

"Free Pint" \& logo, rev. of, 517

Fretwell-Downing, Inc., "UC libranes expand interlibrary loan service," $93-94$

"Fretwell-Downing and ARL collaborate on Scholars Portal Project," 413

Friedman, Arthur, news note, 302

"From cataloger to curator: the Korean exhibits of an accidental ethnic librarian" \& photos., Wakimoto, 431-34, 452

Fujiech, Er, "WSS Significant Achievernent Award goes to Fujiedal Miner, and Stafford," 286

"Further reading," Dutka, 21

G

"Gabriel: the Gateway to Europe's National Libraries" \& logo, rev. of, $826-27$

"Gale launches ebook program," 773

Galloway, Ann-Christe, See also Young, Ann-Cliriste; "Grants and acquisitions," 676-77, 743, 830-31; "People in the Neus", 67881, 744-46,833-35; port, 820

Gardner, Kenry Ann, news note, 454

Garrett, Jeffrey, "Casting a wide net: the Early English Books project meets at Northwesrem," 117-19; photo., 187

Gat. State U., "The citizen in the information age: Georgia State University's creation of al librarian-led freshmen learning community," 276-79; Roxy Theater in Atanta, black-andwhite photo., 329 (photo, cover, no. 5)

"Get involved at ACRL's Legislatuve luncheon," 283

"Get involved with ACRL: volunteer to serve on a division or section committee, ${ }^{\text {" }} 659-61$

"Gift to support new science library at Princeton," 6

Gillett, Theresa, deceased, 604

Gilley, Jennifer, appt., 224

Gilson, Caroline L, rev. ("Pullic Agenda Online" \& logo), 596

Gleason, Maureen, "In the Neus", 4; "News from the field," 5 -8

"Global Exchange" \& logo, rev, of, 44445

Gold, Anna Keller, "Computational science: an Internet introduction" \& logos, 112-16

Goldeman, Gail, revs. ( "USAID" \& logo, 216; "Early Modem Women Database", 596-97)

Golian-Lui, Lindn Marie, appt. \& port., 744

Graf, Francine, port. 821

"Grants and acquisitions," Galloway, 676-77, 743, 830-31; Young, $48,136,221,300-301,378-79,450-52,520-21,600$

Grants (by grantec), Appalachian State U., 378; ARL, 92-23; CSU, Northridge, 676; Center for Research Liloraries, 520; Coll. Cr. for Lilb. Automation, 830; Columbia U., 450, 600; Comell U., 136, 221, 300, 830 -31; Dominicen []., 450; Fmory U., 520; Hore Coll., 48 ; Ind. U., $450-51$; Johns Hopkins U., 520; Nassau Community Coll., 300; NYSHA, 830, NYU, 136, 450; N.C. State U, 300; Northwestem U., Boston, 830; Ohio State U., 676; Or. State U., 600; Princeton U., 6; SOLINET, 743, 830; Southwest Mo. State U, 676; Springfield Coll., 48; SUNY, Albany, 450-51; Syracuse U., 743; Tampa Bay Iith. Consortium, 830; Tex. A8:M U., 92-93; Tulane U., 600; U. of Ill., U-C, 830; U. of Ariz., 221; U. of Ark. 451; UC, Berkeley, 676; LC, San Diego, 600; UCLA, 378, 830; U. of Dubuque, 450; U. of Fla., 136; U. of Ill., 450; U. 
of Ill, U-C, 300; U. of Mich., 221; U. of Miss, 300; U. of Mo., St. Louis, 676; UNC, CH, 378, 450; U. of Pittsburgh, 48, 378, 830; U. of Tenn., 520; U. of Tex. Austin, 743; Western Md. Coll., 48

Grants (by grantor); Ameritech, 48, 450; Biltmore Estate $\mathrm{CO}, 300$; Bobst, Mamdouha "Dodo," 450; Brine, Kevin \& Macteline, 450; Commonwealth of Pa., 48; Delmas (Gladys Krieble) F., 830; Duke (Paul G.) F, 676; E.S.P. Das Educational F., 378; EZ-LSTA Digitization Demonstration Grant, 378; Forest Hist. Soc., 300; Freeman F., 378; Hoover, Samuel H., 48; IMLS, $48,221,300,450,830$ (2); Lewis, Peter B., 6; LSTA, 136, 830; Mellon (Andrew W) F, 136, 221 (2), 300, 378, 520, 600, 676, 830; Miceli (Virginia Brown) estate, 600; Myers, Charles C. \& Romona, 450; NEH, 300, 450-51, 520 (2), 600, 743 (2), 830; NHPRC, 676; NSF, 92-93, 520, 830-31; N.Y. State Dept. of Educ., 300; N.Y State Prog. for the Conservation \& Preservation of Lib. Research Materials, 450; N.Y Times Neediest Fund, 600; Robinson, Thomas E. \& Patricia A. Duke, 676; Tex. Telecommunications Infrastructure Fund, 743 ; Union Pacific Railtroad Corp., 676; USDE, 676, 743; Walton Family Charitable Support F, 451

Greenstein, Daniel, appt., 302

Greenwoxd Publishing, Career Achievement in Women's Studiexs Librurianship, 2002, 285-86, 2003, 589

"Guidelines for academic status for college and university libraians," ACRI, approved 2002,664-65

"Guidelines for curriculum materials centers: draft version," ACIRL, 207-13

"Guidelines for instruction programs in acadernic libraries: a final draft," ACRL, 732-35

"Guidelines, guidelines, and more guidelines," ACRL, 733

"Guidelines regarding thefts in libraries: a draft," ACRL, 360-66 Gunselman, Cheryl, rev. ("Economic Policy Instutute"), 673

\section{H}

Hacken, Richard, photo., 187

Hagness, Carol, news note $\&$ photo., 678

Halın, Trudi Bellardo, news note \& poit., 50

Hakim, Musa Abdul, "Navigating the Web of discourse on the scholarship of teaching and learning an annotated Webliography" \& logos, 502-5

Halgren, Joanne, retired, 680

Hall, Hal W', news note, 381 ; "Science fiction and fantasy a guicle to resources on the Web" \& logos, 652-55

Hallblade, Shirley, appt. 224

Hampel, Edith Baker, deceased, 681

Hampton U., "Tidewater libraries develop new music collection," $552-53$

Hannaford, Willam, retired, 524

Hansen, Carol, "Dance: a guide to Web resources" \& logos, $776-$ 79. "More about dance," $T 79$

Hardesty, Larry, "Demystifying the program selection process. how to submit a successful proposal for the 11 th $\Lambda C R L_{1}$ National Conference," 269-70, 279; "Exciting things happen (9) your library: ACRL advettisements in the Chronicle of higher educalion" \& photo, 586 -87; news nore, 833; news note \& photo., 602; "Tips for a successtul proposal," 270

Harr, Barbara, photo., 379

Harris, Steven R., 'Writers in the libriry: itterary programming on a shoestring" \& bookmark, 423-25

"Harry Potter Premiere Party was held at the Depot Branch of Bowling Green Pululic Lilorary" photo., 5

Hart, Darrick, deceased, 835

Harvard Institutes for Higher Educatson, "ACRL/Harvard leadership Institute," 203, 288, 334, 414; "2002 ACRI/Harvard Leadership Institute," 93

Hayclen, Carla D., "Meet the candidates for ALA president: vote in the election this spring" \& port., 198-201, 203

Hayes, Sherman, "Further reading," 21; "The surprise part of a librarian's life: exhibition clesign and preparation course" \& photos, 19-22

Hedberg, Jane, "Preservation news," 43, 53, 131, 136, 215, 221, 296, $301,370,442,515,594,670,737,825$

Heidom, P Bryan, news note, 50
Helms, Frank $Q$, reired \& photo, 225

Hencken, Louis, photo., 834

Hensley, Randall Burke, "Wins IS Miriam Dudley Instruction Librarian Award" \& port, 285

Heman, Gertrude Becker, deceased, 604

Herold, Irene M. H., appt., 382

Herring, Susun, appt., 302

Herring, Susan Davis, "Wins K. G. Saur Avvalrd" \& port., 287-88

"Hey Fellows," poster, 3 (photo., cover, no. 1)

Hickey, Damon D., "Hints for successful panel presentations: preparing for ACRL's 11th National Conference," 28-29; When changerset instone an analssisof seten academuclibranies derigned by Pem Dean Roger, Aicbileck; 7-8

Hildreth, Charles R., appt., 302-3

Hillen, Charles F., news note \& photo., 522

Hillson, Barbara, rev. ("Gabriel" \& logo), 826-27

Hinchliffe Lisa, photo., 412

Hines, Rich, appt, 679

"Hints for successful panel presentations: preparing for ACRL's 11th National Conference," Hickey, 28-29

Hisle, W. Lee, "A special thanks," 730; "Top issues facing academic libraries: a report of the focus on the Future Task Force," response, 714-15, 730, 789; "Top ixsues fox academic libraries," 714

"History of the guidelines," ACRL, 361

Hogan, Sharon, "A celebration of the life of Sharon Hogan" photo., 560; deceased \& port. 458

Homeland Security Inf Ctr., "NTIS provides Homeland Security Information Center," 773

Hopkins, Dianne McAfee, retired, $603-4$

Houdek, Bob, "Teams and tasks: active bibliographic instruction with high school students in a summer engineering program," $335-37$

Houghton Mifflin Co., "Baker \& Taylor announces e-content agreements," 411

"How practical are the ACRL 'Standards for College Libraries?? Applying standards in the ucademic tibrary," Femekes, 71113

"How to become a serial killer: one approach to the acquisition and retention of periodicals," Christenlserry, 103-5

"How useful is your homepage? a quick and practical approach to evaluating a library's Web site," Adams, 590-92

Howell, Margarct, retired, 304

"HowStuffWorks," rev. of, 738

Hubbard, Willis M (Bill), retired \& port., 53

Huge, Sharon, "Teams and tasks: active bibliographic instruction with high school srudents in a summer engineering program," 335-37

Hugh C. Alkinson Memorial Award, 2002,420; 2003, 588

"Huguenot resistance to the Gregorian calendar reform in France," Larson, 260-61

Huntington Lib., Leab Award, $286-87$

I

"The illusiration is a detail from a water color on silk painting," Miyagi, 637 (photo., cover, no. 9)

"In the Neus", Gleason, 4; Orplian, $90,162,258,330,410,486,550$, 638, 702,770

"Indiana Univ. opens new facility," $703-4$

Ingenta, Inc., "Univ, of Southampton and Ingenta enter strategic partnership," 552

"Ingenta offers advanced deposit," 705-6

"Initiative and Referendum Institute" \& logo, rev. of, 826

Innovation in Instruction Award, 2002, 2865;2003, $588-89$

ISI, Doxtoral Dissentation Fellowship, 2002, 284, 2003, 589; Samue] Lazerow Fellowship, 2002, 281-85; 21003,589

"IMLS issues two Digital Library Forum reports," 6-7

"Instruction for furst-year undergraduates: developing strategies to facilitate their transitions, " ACRL, IS, 196

Instruction Section Publication of the Year Award, 2002, 286; 2003,589

International Scholarly Communications Alliance (ISCA), "Scholatly Communications Allance established," 259, 261

Internet resources ("Biography resources" \& logos, Schreiner, 
32-35, 39; "Complementary and alternative medicine" \& Iogos, Nims, 576-79, 589; "Computational science" \& logos, Gold, 112-16; "Crisis, disaster, and emergency management" \& logos, Courtois, 723-26; "Dance" \& logos, Hansen, $776-$ 79; "Environmental health" \& logos, Riley, 350-54; "Literary theory" \& logos, Roberson, 176-79, 184; "More about dance," Hansen, 779; "Navigating the Web of discourse on the scholarship of teaching and leaming" \& logos, Hakim, 5025; "Science fiction and fantasy" \& logos, Arant, 652-55; "Travel on the Web" \& logos, Coutts, 271-75; "World religions on the Web" \& logo, Jaeger, 426-29)

"Intemet reviews, "Roberts, 44-45, 132-33, 216-17, 297-98, 372-

$73,444-45,516-17,596-97,672-73,738-39,826-27$

"Internet Sacred Text Archive," rev, of, 133

"Invasivespecies.gov" \& logo, rev. of, 132-33

"Invitation to the ACRL President's program in Atlanta. the top

five reasons you need to be there," Van Orsdel, 341-42, 377

Iverson, Debbie, news note \& port., 138

J

Jackson, Ruth, appt. \& port., 744

Jaeger, John, "World religions on the Web: a guide to some of the most helpful sites" \& logo, 426-29

Jenkins, Barbara Baxter, photos., 568, 813

Jenkins, Darrell L , retired, 304

Jenkins, Paul O. "They're not just using Web sites: a citation study of 116 student papers," 164

"Jewish Virtual Lubrary" \& logo, rev, of, 672-73

Job of a lifetime ("Around the world in 100 days" \& photo, Mizzy, 716-17)

"'Job of a lifetime' ideas?", Mizzy, 739

John, Nancy, photo., 560

Johns Hopkins U., "Facing the comperition: the critical issues of reference service," $774-75$

Johnson, Rick, "Online resources," 650; "SPARC and ACRL: working together to reform scholarly communication," 648 51

Jolunson, Wendell, rev. ("Internet Sacred Text Archive"), 133

Jones, Phillip J., "Rethinking library development: the ethical implications of library fundraising," $584-85$, comments, 710 Jones, Rita, photo., 570

Josey, E J., news note, 50

"ISTOR releases language and literature collection," 704

$\mathbf{K}$

K G. Saur Award for Best CERLArticle, 2002, 287-88; 2003, 589 Kanzler, Jon, "The value of campus partnerships in redesigning library instnection: administrators, faculty, and sudents get involved," 345-18

Katharine Kyes Leab and Daniel J. Leab Amenican Bood? Prices Cumern Fxhibition Catalogue Awards, 2002, 286-87; 2003, 589

Kaufman, Paula T., news note \& port., 50

Kawakami, Alice, news note \& port, 678

"Keep informed of legislative and policy issues," 554

Kelly, Maurie Caitlin, ed., Making the grade academic libranes and studentsuccess 261-62(photo)

Kemp, Barbara E., "Named EBSS Distinguished Librarian," 288

Kenyon Coll., "Five years ago ...: comparison charts as a public relations tool," 495-97

Kissane Danny, rev. ("National Consumers Teague"), 216-17

Klassen, Tim, "Computer manuals in the academic library collection improving accessibility," 506-9

Kluwer, "Ovid adds Kluwer's joumals," 94

"The knotty problem of priorities and relationships: a response to the top issues," Baker, 780

"The Knowledge I oom: What Works in Teaching and Leaming" \& logo, rev, of, 217

Kolbzina, Normal, news note, 50

Koepp, Donna, retired, 457

Koppes, Clayton, photo., 413

Kratzert, Mona, "Literary theory; a guide to critical theory resources on the Internet" $\&$ logos, $176-79,184$

Kreiz, Patricia A, photos., 568, 570,813

Krizack, Joan D., news note, 454
Krosch, Penelope, retired, 524-25

Kross, Andrea, ed, Making thegrade academic libmriex and suden succes; 261-62 (photo.)

Krueger, Janice M., ("The Knowledge Loom: What Works in Teaching and Learning" \& logo), 217

LaBaugh, Ross T, "Wins IS Innovation in Instruction Award" \& port, 286

Laite, Berkley, "Does the 'new library model' fit small-and mediumsized libraries? Shippenshurg University believes so," 15-17

Iang, Carol, "Digital diamond sparkles at Temple," 488-89

Lange (Marta)/CQ Award, 2002,285; 2003, 588

Lanham, Allen, photo., 834

Larsen, A. Dean, deceased, 68 -

Larsen, Ronald L., appt., 602

Larson, Jeffry, "Huguenot resistance to the Gregorian calendar reform in France," 260-61; photo., 187

Luzerow (Samuel) Fellowship, 2002, 284-85; 2003, 580

"Leab Exhibition Award winners named" $286-87$

Leab (Kathanine Kyes and Daniel j.) Anerican Book Prices Curvent Exhibition Catalogue Awards, 2002, 286-87; 2003, 589

"The LEAPing' librarian's role in a campus leaming community: helping students get through their freshman year" \& photo., St. Clair, 24-26, 29

Leaming communities ("The 'LEAPing' librarian's sole in a campus leaming community" \& photo., St. Clair, 24-26, 29)

Learning communities for excellence ("The citizen in the information age," Burtle, 276-79; "Developing collalsorative relationships," Lippincolt, 190-92; "Invitation to the ACRL President's program in Atlanta," Van Orsdel, 341-42, 377)

"The leaming community for excellence in academic libranes," ACRL, Annual report, 2001-2002, 795-822

Lee, Christopher A. (Cal), news note \& port., 744

"Legislative advocacy workshop in Aluntes:" 262

Lehner, John, "University Libraries Section at Midwinter. a wrapup of activities," 291-92

"Let freedom read: read a banned brok" \& photo., 553

Letters, 710

Levine, Jennie, photo, 379

Lil, Qualt+, "Academic Health Sciences Libraries and OhioLINK join LitsQual+ survey," 5-6

"Libraty community endorses Digital Media Consumers' Rights Act," 704

$\mathbf{L C}$, "Classification Web available through Library of Congress," 554

"Library of Congress and OCLC release reference service," 487

LSTA, "Syracuse U. study slows LSTA funding spurred library investment, " 639

"Library-sponsored faculty book-buying trips: a look at a different approach to collection development," Brantz, 264-66, 292

LSSI, "Siris partners with LSSI for integrated virtual reference," 639)

"The library takes the lead: Wichita State University Libracy proposes a university-wide Intemet policy," Smith, 499-500, 509

"The library's role in distance education: survey results from ACRL's 2000 academic libruy trends and statistics", Thompson $338-40$

Linden, Julte, rev. ("Statistical Assessment Service (STATS)" \& $\log 0)_{1} 4445$

Lindquist, Thea, "Back to Europe: ACRL at the 53rd Frankfurt Book Fair" \& pliotos., 204-206, 220

Linke, Etika C., "Financial report" \& port, 814-18; photos., 568 570,813

Lippincott, Joan K., "Developing collaborative relationships. librarians, students, and faculty creating learning communities," $190-92$

"Literary theory: a guide to critical theory resources on the Intemet" \& logos, Roberson, 176-79, 184

Little, Rosemary, deceased, 681

"Living the Futture 4: collaboratively speaking: a library conference on organizational renewal, "Bowlby, 511-12,521

Lolif, Kenneth A., deceased \& port., 525 
"Looking for a few good questions: it really is process, not product," Rabinowitz, 492-93

Lougen, Colleen, rev. ("Financial Markets Center" $\&$ logo), 738 39

"A low-tech approach: working with persons with mobility and speech disabilities in an academic library" \& photos., Forto, $708-10$

Lowry, Charles, photo, 379

Lynden, Frederick, photo., 187

\section{$\mathbf{M}$}

McAndrew, Rosemary, "Tips for successhul workshops," 181

"MoCracken and Yellowstone sign agreement," 706

MoCracken Research Lib., "McCracken and Yellowstone sign agreement," 706

McCulley, Carol, rev. ("National Foundation for Infectious Diseases" \& logo), 298

McCurdy, Faith, photo., 521

McCurdy, Sheila, photo, 521

McDermott, Patrice, "Washington hotline," 214, 441, 452

Mclaughlin, Brian, news note, 454

McReynolds, Rosalee, deceased \& port., 746

Major, Jean A., retired \& port., 680

Making the grade crademic libnaries and student succers, Kelly, ed, 26162

Maloy, Frances, "Meet Dumont and Maloy-candidates for ACRL president," 784

"Managing reference e-mail in an archival setting: tools for the increasing number of reference queries, "Bell, 99-101

"MARC records available for Wright American Fiction," 771

Marcum, James W., appt., 679

"Mark your calendar! ACRL to offer two workshops in Philadelphia," 772; ALA, Midwinter Meeting, 2003, 704

Marta Iange/CQ Award, 2002, 285; 2003, 588

Martin, Susan K, "ACRL takes up the challenges of scholarly communication: the year ahead for the new program officer, 786-87, 793; "Susan Martin is new ACRL visiting program officer" \& port., 703

Martinus Niphoff Intemational West European Specialist Study Grant, 2002, 94, 187, 260-61

"Maryland Interlibrary Consortium chooses Endeavor," 332

Mason, Elisa, rev. ("UNHCR: the UN Refugee Agency"), 516-17

Massey-Burzio, Virginia, "Facing the competition: the critical issues of reference service," 77475

"Matrix: a Scholarly Resource for the Study of Women's Religious Communities from $400-1600 \mathrm{CE}^{\prime \prime} \&$ logo, rev, of, 444

Matthews, Cathy, "Ask a librarian LIVE: specialist and broadbased reference capacities expanded by new software," 280 81

Maynard, James Edmund, deceased, 53

Means, Pat, "Abell Library at Austin College's bulletin board" photo., 587

"Meet Dumont and Maloy — candidates for ACRL president," 784

"Meet the ACRL staff," 820-22

"Meet the candidates for ALA president: vote in the election this spring" \& ports, 198-203

"Members running for ALA Council," ACRL, 202

Mento, Barbara A news note, 381

"MetaScholar Initiative established," 551

Mich State U., "A low-tech approach: working with persons with mobility and speech disabilities in an academic library" \& photos., 708-10

Middeldorp-Crispijn, Ineke, photo, 187

Mihalega, Anna, photo., 716

"Millersville Univ. sends books to Africa," 262

Miner, Meg, "WSS Significant Achievernent Award goes to Fujieda, Miner, and Stafford," 286

Miriam Dudley Instruction Librarian Award, 2002, 285; 2003, 588

"The Mississippi Writers Page" \& logo, rev, of, 597

Mitchell, Bill, news note, 381

Mitchell, w. Bede, photo., 570

Mryagi, Fumiko, "The illustration is a detail from a water color on silk painting, "637 (photo., cover, no. 9)
Mizzy, Danianne, "Around the world in 100 days" \& photo., 716 17; "Job of a lifelime' ideas?", 739

"Modeling and the use of graphics in Web tutorials: a lesson from social leaming theory" \& photos., Suarez, 95-96, 119

Mont. State U., Bozeman, "We are all reference librarians: using communication to employ a philosophy of access for caralogers," 168-70

"More about dance," Hansen, 779

Morgan, Famela D., news note \& photo., 522

Morgan Lib., "Thaw Conservation Center opens at Morgan Library, 93

Moukdad, Hardar, news note, 454

Moyo, Lesley, appt., 138

Mueller, Dawn, port., 821

Music pynotechnical diabolical and huny-butical lithograph, Daumier, 701 (phota, cover, no. 10)

Myers, Marilyn, appt. \& port, 523

\section{$\mathbf{N}$}

"National Consumers League," rev, of, 216-17

"National Foundation for Infectious Diseases" \& logo, rev. of: 298

"NISO establishes Networked Reference Services Committee," 165

Natl. Lib. Legislative Day, "Get involved at ACRL's Legislative luncheon," 283

Natl. Lib. of China, "Columbia Univ. contracts with National Library of China," 259

"National Library Service for the Blind and Physically Handicapped announces telecommunications initiatives," 331-32

"National Library Week grant available to promote the role of librarians," 553-54

"The National Park Service Archeology and Ethnography Program," rev. of, 827

"NTIS provides Homeland Security Information Center," 773

Natl. Underground Railroad Freedom Center, "Univ. of Cincinnati partners with Underground Railtoad Center, " 554

"Navigating the Web of discourse on the scholarship of teaching and learning: an annotated Webliography" \& logos, Hakim, $502-5$

"Need to develop a plan to support distance ed?: take ACRL's new online course," 665

Nehlig, Mary E., retired \& photo, 225

Neie, Philipp, photo., 187

Nelson, William N., "How practical are the ACRL 'Standards for College Libraries'? Applying standards in the academic library," 711-13

Nerz, Honora F., news note \& photo., 50-51

netLibrary, "OCLC offers to purchase netLibrary," 5

netLibrary Ready Reference Coll., "BCR activates new netLibrary Ready Reference Collection, "640-41

"New CSU information competence Web site," 64:1061, correction, 108

"New definition of America enters OED.com," 551-52

"New publications," Eberhar, 46 ( $\&$ photo), 13435 ( $\&$ photo), 218-20 (\& photos.), 299 (photo.), 301, 375-77 (\& photo) 447-48 (\& photo), 518-19, $598-99$ ( $\&$ photos.), 674-75, 740 41 (\& photos), $828-29$ (\& photo)

New realities, new relationship ("Crossing borders, "Dancik, 656 , $677 ;$ "The double life of the college campus," Welbum, 718 20; "New realities, new relationships for academic and research librarians," Spalding 580 -82; "Old borders, new borders, bridges, and new relationships, "Rettig, 790-93)

"New realities, new relationships for academic and research librarians: the new presidential theme," Spalding, 58082

"New roles and global collaboration the fruits of international exchange" \& photos., Comer, 106-8

"New titles published by ACRL" \& photos, , 7-8

"New version of WilsonWeb launched," 771

"New ways to acquire old books: adding out-of-print titles to the library's collection," Bickers, 173-75, 188

"New Web site profiles Sanford Berman papers at UIUC," 164-65 
NYPL, Leab Award Special Commendations for Electronic Exhibitions, 28687

"NYPL unveils new South Court building," 331

"New Yonk Times and Wall Street Joumal fully digitized," 552

"News from the field," Gleason, 5-8; Orphan, 91-94, 163-66, $259-62,331-34,411-14,487-90,551-54,639-41,703-6,771-$ 7

"News from the University Libraries Section," 562-63

Nilson, Julieann V., deceased, 835

Nims, Julia K. "Complementary and altemative medicine: an overview of nontraditional medicine on the Web" \& logos, $576-79,589$

Nisbet, Miriam, "Washington hotline," 669

Nolting Daniel Lincoln, rev. ("Web Developer's Virtual Library"), 445

Norfolk State U., "Tidewater libraries develop new music collection," 552-53

N. Central Coll., "The illustration is a detail from a water color on silk painting," 637 (photo, cover, no. 9)

"Northem Light discontinues free public access to Web search," 91

Northwestem IJ., "Casting a wide net: the Early English Books project meets at Northwestern," 117-19

"Northwestem University creates Cyber Cafe in library" \& photo. 165

Nugent, Christine R., appt. \& port., 523

0

Oberlander, Cyril, "Access services and RILI: great partnership opportunities," 666-68

Oberlin Coll., "Excellence in Academic Libraries winners, " 196 (8 photo.)

"Oberlin College Libraries received the 2002 Excellence in Academic Libraies Award in a ceremony held on the Oberlin campus on May 1" photo., 413

Oberly (Eunice Rockwell) Award, 2003, 589

OBrien, Nancy Patricia, ed, Dinectory of text collections in accidemic professional, and nexarch libmaries, published, 92 (\& photo)

OCLC, "First project underway at OCLC's new preservation center," 641; "Library of Congress and OCLC release reference service, " 487

"OCLC offers to purchase netLibrary," 5

Ohio U., "Teams and tasks: active bibliographic instruction with high school students in a summer engineering program, "33537

OhioLINK, "Academic Health Sciences Libraries and Ohiol.TNK join LibQual+survey," $5-6$

"OhioLINK delivers video on demand," 411

Oka, Christine, news note, 454

Olanyk, Tracey, photo., 716

"Old borders, new borders, bridges, and new relationships transforming academic reference service," Retrig, 790-93

Old Dominion U., "Tidewater libraries develop new music collection," 552-53

O'Neal, Tracy W., Roxy Theater in Atlanta, black-and-white photo., 329 (photo., cover, no. 5)

"Online resources," Johnson, 650

"Open forum on ACRL the association of the future," 781

Or. State U. "Pauling research notebooks released online," 261

"Oregon State Univ. to study student use of paper and electronic resources," 552

"Original valentines," 89 (photo, cover, no. 2)

Orphan, Stephanie "In the News", 90, 162, 258, 330, 410,486, $550,638,702,770$; "News from the field," 91-94, 163-66, 259-62, 331-34, 411-14, 487-90, 551-54, 639-41, 703-6, 771-73; port., 821; "Stephanie Orphan named Web product development specialist for ACRL and editorin-chief of CERL news', 5

"Ovid adds Kluwer's joumals," 94

Owens, Tom, deceased, 304

$O E D$, "New definition of America enrers OED.com," 551-52

Oxford U. Press, "Baker \& Taylor announces e-content agreements," 411
Pace, Andrew K., news note 8 port, 454

Paine, Nancy, news note, 522

Palmer, Carole, news note, 50

Palmer, Kristina, photo., 332

"Panel session on new IS research agenda to be held at ACRL National Conference," 773

Parker, Elise, port., 821

Pamell, Jerry, "Further reading " 21 ; "The surprise part of a librarian's life: exhibition design and preparation course" \& photos., 19-22

Par, Virginia $H$, retired, 525

Paster, Gail Kem, appt. \& port., 455

Pastine, Maureen, news note \& port., 833-34

Patrick, Susan, "Ask a librarian LIVE: specialist and broad-based reference capacities expanded by new software," $280-81$

Pauling, Linus, "Pauling research notebooks released online," 261

"Pauling research notebooks released online," Or. State U., 261

"People in the Neus", Galloway, 678-81, 744-46, 833-35; Young: $50-53,138-39,223-25,302-4,381-83,454-58,522-25,602-4$

Perez, Derrie Roark, news nore, 602

Penushek, Diane, appt., 138

Petrowski, Mary Jane, "ACRL honors the 2002 award winners: recognizing professional achievement," 194-06; "Mary Jane Petrowski named ACRL senior associate executive director" \& port., 91; port, 822

Pfahler, Sandy, retired, 604

Phipps, Shelley, photo., 564

Phipps, Shelley E. "Named Academic/Research Librarian of the year $^{n}$ \& photo., 161, 195 (port, cover, no. 3)

Pierpont Morgan Lib. Publications, Leab Award, 286-87

Podracka, Dana, Don't forget the Fairy, frontispicoe, walercolor illus 409 (photo., cover, no. 6)

"Political cartoon collection available through Digital Library of Georgia," 331

Poole, Francis, "Copyright town meeting: intcllectual property and multimedia in the Digicul Age, ${ }^{n} 182-84$

Popko, John, "ACRL andidates for 2002: leam who's runining for office" \& port., 36-37, comection, 139; "Cannon and Popko share plans for ACRL: prepdre to cast your vore in the election this spring" \& port, $124,126-28$

Popular Culture Assn., "Call of popular culture papers," $488-89$

Porter, G. Margaret, "The value of campus partnerships in redesigning library instruction: administrators, faculty, and students get involved," $345-48$

"Poster session presenters sought for ACRL National Conference, $" 641$

Prange, Polly, photo., 379

Prange, Winfred, photo., 379

"Preparing for ACRL's 11th National Conference: how to create competitive contributed papers," St. Clair, 180-81

"Preservation news," Hedberg, 43, 53, 131, 136, 215, 221, 296, 301, $370,442,515,594,670,737,825$

"President's budget indudes $\$ 10$ million to recuit new librarians," 163

Princeton U., "Gift to support new science library at Princeton" 6 Proquest, "ABI/INFORM subscribers receive expanded access lo backfiles," 706; "New York Timesand Wall Sireet Joumallully digitized" "552; "Village Voice Pubs added to Alt-Press Watch," 400

"Public Agenda Online" \& logo, rev. of, 596

Publications in Librarianship (PIL), "Charles A. Schwartz gamed new PIL editor by ACRL board," 261

Punches, Caroline J., letter to the editor, 710

Quarton, Barbara, "Five steps to an effective intemship program: providing a meaningtul experience for intems and librarians," $109-11$

Rabinowiz, Celia, “Looking for a few good questions. it really is process, not product," 492-93 
Rader, Hannelore, photo. 332

Rapple, Brendan A., news note, 381

"RBMS to offer $43 \mathrm{rd}$ preconference in Atlanta," ALA, Annual Conference, 2002, 166

Rasco, Paul, news note, 522

Rata, Alisa, news note, 302

"Receive advance notice of CERL news contents," 554

RFB\&D, "Digitally recorded textloooks available though RFB\&D," 641

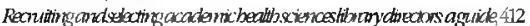

"Register for ACRI preconferences," 258

Reichel, Mary, "Message from the president" \& port., 796-97; photas., $187,413,560,564,568,570,813$

Remington, David Gray, retired, 457

Renfrow, Debbi, rev. "The Mississippi Writers Page" \& logo), 597

"Resolution honoring Marinus Nijhoff Intemational" \& plıoto. 187

"Rethinking library development: the ethical implications of library fundraising," Jones, 584-85, comments, 710

Retirements, 53, 139, 225, 304, 383, 457, 524-25, 603-4, 680 81, 746

Rettig, James, "Old borders, new borders, bridges, and new relationships: transforming academic reference service," 790 93

R.I. School of Design, "Fleet donates historic building to RISD library," 261

Richards, Bruce, photo, 107

Richards, Susan, "Tips for successtul workshops," 181

Richardson, John V., news note \& port., 302

Richey, Debora, "Literary theory: a guide to critical theory resources on the Intemet" \& logos, 176-79, 184

Ricker Alison S., "New roles and global collaboration: the fruits of international exchange" \& phoros., 106-8

Riley, Ola Carter, "Environmental health: sites that focus on protecting our natural resources" \& logos, 350-54

Roberson, Julie, "Literary theory: a guide to critical theory resources on the Intemer" \& logos, 176-79, 184

Roberts, Bill, retired, 225

Roberts, Joni R., "Internet reviews," 44 45, 132-33, 216-17, $297-98,372-73,444-45,516-17,596-97,672-73,738-39$, $826-27$

Roca, Joan, appt. \& port, 303

"RIT's Wallace Library ads CHOICE Reviews to its OPAC, 411

Rockwood, Irving, port., 822

Rodkewich, Patricia, retired, 525

Rose, Rolbert F., phows., $568,570,813$

"A round of applause for ACRL's 2002 award winners: the second installment of winners," Sherrod, 284-88

Routledge Press, Significant Achievement in Women's Studies Librarianship, 2002, 286; 2003, 589

Roxy Theater in Adlanta, black-and-white photo., O'Neal, 329 (photo, cover, no. 5)

Rubin, Clarie B., "Crisis, disaster, and emergency management: Wels sites for researchers" \& $\log x$ s, $_{3} 723-26$

Ruscella, Phyllis, appt., 523, 602

Ruschoff, Carlen, news note, 51

Russel, Carrie, "Washington hotline," 824

Rutherford, Shauna, "The wired classroom: dream and reality," $642-45$

Ryan, John R, photo., 521

Ryan, William L, retired, 680-81

Ryerson U., "Ask a libranan LIVE: specialist and broad-based reference capacitices expanded by new software," 280-81

"SAGE Publications to offer collections online," 639

Saines, Sheri, "Teams and tasks: active bil)liographic instruction with high school students in a summer engineering program," 335-37

St. Clair, Gloriana, "Preparing for ACRL's 11th National Conference: how to create competitive contributed papers," $180-81$

St Clair, Inda, 'The 'LFAPing' librarian's role in a campus leaming community: helping students get through their freshman year" \& photo., 24-26, 29
St. Petersburg Junior Coll., "Community College awards go to Steinhoff and St. Petersburg Junior College," 420, 425

Sakaguchi, Eiko, photo, 379

Sales, Vivienne, rev ("Free Pint" \& logo), 517

Samuel Lizerow Fellowship, 2002, 284 85; 2003, 589

Saur (K. G.) Award for Best CGRL Article, 2002, 287-88; 2003 589

Saye, Jerry, news note, 455

Schatz, Buce R., news note, 223

Schmidr, Diane, news note, 744

Sclineider, Joanne A, appt. \& port, 745

Scholarly communication ("ACRL takes up the challenges of scholarty communication," Martin 786-87, 793; "ACRL's new scholarly communication initiative," English, 356-658; "Online resources," 650; "SPARC and ACRL," Johnson, 648 51)

"Scholarly Communications Alliance established," 259, 261

"SPARC and ACRL: working together to reform scholarly communication," Johnson, 648-51

Schreiner, Susan A., "Biography resources: finding information on the famous, infamous, and obscure" \& logos, 32-35, 39

Schwartz, Charles A " "Named new PIL editor by ACRL board," 261

"Science fiction and fantasy: a guide to resources on the Web" \& logos, Arant, 652-55

Seadle, Micl hael, "You don't need to know Geman to participate in ARL's German Resources Project," 705

Seaman, David, appt., 679

"Section committee volunteer form," ACRL, 663

"Semester at Seal Librarian," 717

Serials Solutions, "Swets Btuckwell and Serials Solutions collaborate to ease e-joumal management, "413-14

"Slrare your thoughts and ideas," CERL neus, 715

Sheehy, Carolyn, news nore, 602

Sherif, Ann, photo., 413

Sherrod, Stephanie, " $\Lambda$ CRL honors the 2002 award winners recognizing professional achievement," 194-96; "ACRL's 2003 awards program: recognizing outstanding achievements in academic librarianship," 588-89; "Atkinson and CJCLS award committees announce 2002 winners: the final installment of ACRL award winners," 420,425; port., 822; "A round of applause for ACRL's 2002 award winners: the second installment of winners," $284-88$

"Shlhll2h! No laughing allowed," 333

Shippensburg U., "Does the 'new library model' fit small- and medium-sized libraries? Shippensburg University believes so," 15-17

Shirk, Gary, photo., 564

Shirman, Bella, retired, 225

Shoshon, Ohara, "Yanagibashi bridge in the snow, "color woodblock print (alternate title: "Two women crossing a bridge on a snowy day"), 769 (photo, cover, no. 11)

Significant Achievement in Women's Studies Librarianship, 2002 $286,2003,599$

Sims, Arlie, photo, 412

"Siris partners with LSSI for integrated virtual reference," 639

Sirsi, "Alaska libranes select Sirsi's Unicorn," 554; "EBSCO and Sirsi form content partnership," 772-73; "Siris partners with LSSI for integrated virtual reference," 639

"Sirsi and DRA complete merger," 92

"Site license edtion of ChoiceRevieus.online now available," 331

Slater, Diana, news note \& photo., 678

Slippery Rock U., Don't fonget the Fainy frontisphece, watercolor illus. 409 (photo., cover, no. 6)

Smeeton, Donald Dean, appt., 745

Smith, Barlyara Leigh, port., 556

Smith, Beth A. "The libary lakes the lead: Wichita State University Library proposes a university-wide Intemet policy," 499-500, 509

Smidh, C. Brian, revs. (

Smith, Cheryl, "The value of campus partnerships in redesigning library instruction: administrators, faculty, and students get involved," 345 - 88

Smith, Donald T., deceased, 458 
Smith, Scott, photo., 413

Smith Bregoli, Marilyn, appt., 52

Snelson, Pamela, photo, 813; photos., 568,570

Somers, Michael A., "Biography resources: finding information on the famous, infamous, and ohscure" \& logos, 32-35, 39

Sonntag Blay, liana L., news note, 51

SOLINET, "MetaScholar Initiative established," 551

Spalding, Helen H., ACRL, president \& port., 436-37; "Message from the vice-president" \& port., 798-99; "New realities, new relationships for academic and research librarians: the new presidential theme," $580-82$; news note \& photo., 834; photos., $568,570,813$

Spear's Model Village, illus., 549 (photo., cover, no. 8)

Spencer, D. Brett, "Boosting libraries at university orientations: designing promotional booths" \& photo., 418-19; "Tips for creating display booths," 419

Stackpole, Iaurie, news note, 381

Stafford, Beth, "WWS Significant Achievement Award goes to Fujieda, Miner, and Stafford," 286

Stalker, Dianne, appt., 138

Stam, David H., news note, 455

Standants and assessment for academic librarie: a wonkbook, ACRL standards \& guidelines, 712

"Statistical Assessment Service (STATS)" \& logo, rev. of, 44-45

"Stay up-to-date on association activities and opportunities, ${ }^{2} 554$

Steinhoff, Cynthia K., "Community College awards go to Steinhoff and St. Petersburg Junior College" \& port., 420, 425; port., 194

"Stephanie Orphan named Web product development specialist for ACRL and editor-in-chief of CGRL news', 5

Stoffan, Mark A., rev. ("U.S. Army Center for Military History" \& $\log 0), 45$

Stone, Elizabeth W, deceased, 304

Strauch, Katina, "Meet the candidates for ALA president: vote in the election this spring" \& port, 198-201, 203

Strmad, Benita, photo., 419

Suarez, Doug, "Modeling and the use of graphics in Web tutorials: a lesson from social learning theory" \& photos., 95-96, 119

"Subject access in an interdisciplinary environment: meaninghul signposts must be created, "Vaver, 415-16

Sugarman, Tammy S., "The citizen in the information age: Georgia State University's creation of a librarian-led freshmen learning community," 276-79

Sullivan, Maureen, "Living the Future 4 : collaboratively speaking: a library conference on organizational renewal," 511-12, 521

Surman, Tina, letters to the editor, 710

'The surprise part of a librarian's life: exhibition design and preparation course" \& photos., Dutka, 19-22

Sulter, Sem, photo., 187

Swain, Richard H., appt., 602

"Swets Blackwell and Serials Solutions collaborate to ease ejoumal management," 413-14

"Swets Blackwell sponsors WESS Martinus Nijhoff Sudy Grant," 94

"Syracuse U. study shows ISTA funding spurred library investment," 639

T

Tabb, Winston, appt., 602

Tanner Anne, news note, 223

"Tarlton Law Library introduces millionth book," U. of Tex., Austin, 94

Taylor, Arlene G., news note, 223

"Teams and tasks: active bibliographic instruction with high schoo" students in a summer engineering program, " Huge, 335-37

Temple U., "Digital diamond sparkles at Temple," 488-89; Before suinset biry a US. goumment bond of the 2ndLibery Loan of 1917 , poster, 485 (photo., cover, no. 7)

Tennant, Claudette, "W/ashington hotline," 129

Terry, George D., deceased, 53, correction, 225; deceased \& port., 225

"Texas A\&M University libraries and ARL receive NSF grant," $92-93$

"Thaw Conservation Center opens at Morgan Library, "93
"There's still time to submit a proposal for the ACRL 11th National Conference," 340

"They're not just using Web sites: a citation study of 116 student papers, "Jenkins, 164

Thompson, Hugh, "The library's role in distance education: survey results from ACRL's 2000 academic library frends and statisics', $338-40 ;$ port., 822

Thompson, Jarnes C., retired, 225

Tiblin, Mariann, retired 525

"Tidewater libraries develop new music collection," 552-53

Tierney, Barbara, "Charlotte on a shoestring: public art, waterscapes, historic sites, and dining" \& photos., 646-47; "Charlotie 'revs up' for ACRL: tours and activities in the 2003 ACRL National Conference city" \& photos., 728-30

"Tips for a successful propasal," Hardesty, 270

"Tips for creating display booths," Spencer, 419

"Tips for successful exhibits," Wakimoto, 433

"Tips for successful workshops," McAndrew, 181

Toblin, Lynne C., news note, 454

Toomer, Clarence, appt., 52

"Top issues facing academic libraries: a report of the focus on the Future Task Force," Hisle, response, 714-15, 730, 789

"Top issues for academic libraries," Hisle, 714

"Toronto, 2003: it's closer than you think," ALA, Annual Conference, 2003,490

Thate, sabhatical, and sudy leavepolicies incollege libnries (CIP note *30) published, ACRL, 92

"Travel on the Web: sites to help you plan your vacation" \& logos, Coutts, 271-75

Treadwell, Jane B., appt., 455

Trejo, Arnulfo deceased, 604

Tulis, Susan E., news note, 678

"2000 ACRL statistics at your fingertips" \& photo., 94

"2002 ACRL/Harvard Leadership Institute," 93

"2002-03 ACRL chapter conferences/events," 722

"Two wornen crossing a bridge on a snowy day" color woodblock print, Shoshon, 769 (photo., cover, no. 11)

$\mathbf{U}$

"UNHCR: the UN Refugee Agency," rev. of, 516-17

"U.S. Amy Center for Military History" \& logo, rev. of 45

U. of $\mathrm{Al}$.. "Boosting libraries at university orientations: designing promotional booths" \& photo., 418-19

U. of Alaska, "Alaska libraries select Sirsi's Unicorn," 554

U. of Ariz., "Living the Future4: collaboratively speaking: a library conference on organizational renewal," 511-12,521

"University of Arizona to hold conference on organizational change," 6

U. of Calgary, "The wired classroom: dream and reality," $642-15$

"UC libraries expand interlibrary loan service," 93-94

U. of Chicago, Leab Award, 286-87

"Univ. of Cincinnati partners with Underground Railroad Center," 554

"University of Georgia library partners wilh Foot Soldier Project for Civll Rights Sudies," 91

U. of ILl., U-C, "New Web site profiles Sanford Berman papers at UIUC," $164-65$

U. of Kan., "Consortial preservation management: a new model for library preservation administration," 572-74; "How to become a serial killer one approach to the acquisition and retention of periodicals," $103-5$

U. of Louisville, "Managing reference e-mail in an archival setting: tools for the increasing number of reference queries," 9 ? 101

"University of Louisville becomes newest ARL member, "487

U. of Mo., Kansas city, "New ways to acquire old books: adding out-of-print titles to the library's collection," 173-75, 188

"University of Missouri-Kansas City Info Commons wins design awards," 488

"Univ. of Nevada unveils Nevada Votes".", 704-5

U. of N.B, "Canadian poetry database launched," 414

UNC, Wilmington, "Further reading," 21; "The surprise part of a libranan's life: exhibition design and preparation course" \& photos., 19-22 
"UNC Chapel Hill offers bachelor's degree in information science," 487

"UNC Greensboro joins ASERL," 412

U. of Notre Dame, "The value of campus partnerships in redesigning library instruction: administrators, faculty, and students get involved," 345 - 48

"Univ. of Oklahoma's athletics department and university libraries create partnership," 411-12

U. of Pittsburgh, "Around the world in 100 days" \& photo., 716 17

"University of Pittsburgh Chinese document delivery service continues," 7

"Univ. of Southampton and Ingenta enter strategic partnership," 552

"University of Southern Califomia's Doheny Memorial Library reopens," 8

U of Tenn., "W/riters in the library: literary programming on a shoestring" \& bookmark, 423-25

"University of Tennessee grad students suppon the library," 413

U. of Tex., Austin, "Tarlton Law Library introduces millionth book" $" 94$

U. of the Arts, "Yanagibashi bridge in the snow," color woodblock print (alternate title: "Two women crossing a bridge on a snowy (ay"), 769 (photo, cover, no, 11)

U of the Sciences at Philadelphia, "How useful is your homepage? a quick and practical approach to evaluating a library's Web site," $590-92$

U. of Utah, "The 'LEAPing' librarian's role in a campus learning community: helping students get through their freshman year" \& photo., 24́ 26, 29

U. of Wash, "Shhhhh! No laughing allowed," 333

"University Libraries Section at Midwinter: a wrap-up of activities," Zimmeman, 291-92

"USAID: the United States Agency of International Development" \& logo, rev. of, 216

\section{$\mathbf{v}$}

Valentine, Barbara, rev. ( "Code Talk" \& logo), 132

"The value of campus partnerships in redesigning library instruction: administrators, faculty, and students get involved," Escobar, 345- 18

Van Orsdel, Lee C., "Invitation to the ACRL President's program in Atlanta: the top five reasons you need to be there," 34142,37

Vaver, Anthony T., "Subject access in an interdisciplinary environment meaningful signposts must be created," 415 16

Vernon, Christie, deceased, 525

Vikor, Desider, photo, 379

Viles, Ann, "Fast Facts," 86, 158, 254, 326, 406, 482, 546, 634, 698, conrection, $720,766,850$

"Village Voice Pubs added to Alt-Press Watch," 490

Va. Tidewater Consortium, "Tidewater libraries develop new music collection," 552-53

"Volunteers needed at Charlotte conference," 773; ACRL, National Conference, 2003, 706

\section{$\mathbf{W}, \mathbf{X}$}

Wakimoto, Jina Choi, "From cataloger to curator: the Korean exhibits of an accidental ethnic librerian" \& photos., 431-34, 452; "Tips for successful exhibits," 433

Walden, Bartara, photo, 187

Walker, Dale, letters to the editor, 710

Walker, Lynn Wesley, deceased \& port., 458

Wall Street Journal, "New Yonk Times and Wall Street Joumal fully digitized," 552

Waller, Darlene, news note, 138

Walsh, Sylvia, deceased, 604

Wand, Patricia A., photos., 568, 570, 813

"Want to learn more about implementing the 'Standards for College Libraries"'? ACRL standards \& guidelines, 712

"Washington hotline," Bowman, 368, 373; Bradley, 41, 129, 214, $294,441,452,669,736$; Russell 824

Wasserstrom, Amy, photo., 379
Waugh, Kappa, cartoons, 6, 92, 163, 259,331, 411, 487, 551, 639, 703, 771

The way I seeit ("Access services and RILI," Oberlander, 666-68; "Does the 'new library model' fit small- and medium-sized libraries?", Laite, 15-17; "Facing the competition," MasseyBurzio, 774-75; "Looking for a few good questions," Rabinowitz, 492-93; "Rethinking library development," Jones, 584 -85, comments, 710; "Subject access in an interdisciplinary environment," Vaver, 415-16)

"We are all reference librarians; using communication to employ a philosophy of access for catalogers, "Carver, 168-70

"Web Developer's Virtual Library," rev. of, 445

Webber, Sheri, revs. ( "American Museum of Natural History Congo Expedition (1909-1915"), 373; "The National Park Service Archeology and Ethnography Program" ${ }^{\prime \prime}$ 827)

Weiner, Suzanne T., news note \& photo., 50-51

Weinstein, Lois, news note, 678

Welbum, William C. "The double lffe of the college campus: striking a balance between reality and expectations," 71820

"We're looking for a few good men and women: ACRL seeks nominees for office," $282-83$

Werner, Gloria, retired, 383

Westem Ky. U., "Harry Potter Premiere Party was held at the Depot Branch of Bowling Green Public Library" photo., 5

Wheelin, Belle, "Charlotte keynote speakers," 706

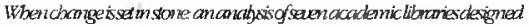
by Perni Dean Kugers, Architecls, Crosbie, 7-8

White, Peggy, "The wired classroom: dream and reality," 64245 Whyte, Susan Barnes, "ACRL programs inspire excellence: the President's Discussion Group at Midwinter," 189, 192

Wichita State U., "The library lakes the lead: Wichita State University Library proposes a university-wide Internet policy," $499-500,509$

Wider, Eve, photo., 716

Wielhorski, Karen, appt., 455

Williams, Sylvia Murplyy, photo., 834

Willis, Paul A., appt., 455-56

Wilson, Lizabeth (Betsy), photo, 568,813

Wilson Web, "New version of WilsonWeb launched," 771

"Wilson Web offers increased access to full-text periodicals," 641

Winters, Joan, news note, 834

"The wired classroom: dream and reality," White, $642-45$

Wojcik, Frank M., "Five years ago ...: comparison charts as a public relacions tool, "495-97

Worcester Polytechnic Inst., "Becoming part of the course: using Blackboard to extend one-shot library instruction" \& photos., 11-13,39

"World religions on the Web: a guide to some of the most helpful sites" \& logo, Jaeger $426-29$

Wright American Fiction, "MARC records available for Wright American Fiction," 71

"Writers in the library: literary programming on a shoestring" \& bookmark, Harris, 423-25

$\mathbf{Y}$

"Yanagibashibridge in the snow," color woodllock print (altemate title: "Two women crossing a bridge on a snowy day"), Shoshon, 769 (photo., cover, no. 11)

Yeakley, Leslie, news note, 454

Yellowstone Natl. Park Research Lib. and Archives, "MoCracken and Yellowstone sign agreement," 706

"You don't need to know Gennan to paricipate in ARL's German Resources Project," Seadle, 705

Young, Ann Christe, See also Galloway, Ann-Christe; "Grants and acquisitions," 48, 136, 221, 300-301, 378-79, 450-52, 520-21, 600 ; "People in the News", 50-53, 138-39, 223-25, 302-4, 381$83,454-58,522-25,602-4$

Young, Arthur P., news note, 51

Yu, Priscilla, news note, 744

$\mathbf{Z}$

Zimmeman, Julia, "University Libraries Section at Midwinter: a wrap-up of activities," 291-92 


\section{The Universe is Expanding and}

\section{So Are Your Information Resources}

Coming Spring 2003

Over 70 Years of Science - Online

Annual Reviews will offer a comprehensive electronic collection of content of all Annual Reviews series dating to the first volume of Annual Review of Biochemistry - available online.

Spanning the Biomedical, Physical and Social Sciences, this reserve of knowledge will allow the scientific community immediate access to over 835 volumes from Annual Reviews $-18,000$ critical authoritative reviews including grayscale and color figures, charts, tables and cited literature - via full-fext searchable PDFs.

Visit Annual Reviews at Booth \#637 at the ACRL 11th National Meeting

For more information Contact Annual Reviews Site License Department Call toll free (US/Canada): $800-523.8635$

or $650,493,4400$ Worldwide Email: sitelicense@annualreviews.org www.annualreviews.org

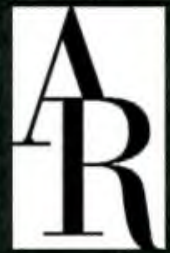

